\title{
Artocarpesin Prevents Collagen Induced Platelet Aggregation and Clot Retraction Through Cyclic Nucleotides and Dephosphorylation of MAPKs
}

\author{
Jung-Hae Shin
}

Kwandong University

Muhammad Irfan

University of Illinois at Chicago

\section{Yuan Yee Lee}

Kyungpook National University

\section{Man Hee Rhee}

Kyungpook National University

Hyuk-Woo Kwon ( $\nabla$ kwonhw@kdu.ac.kr)

Far East University

\section{Research Article}

Keywords: Artocarpesin, Ca2+ mobilization, Serotonin secretion, allb/B3 affinity, Clot retraction, cAMP and cGMP.

Posted Date: March 3rd, 2021

DOl: https://doi.org/10.21203/rs.3.rs-258116/v1

License: (9) (1) This work is licensed under a Creative Commons Attribution 4.0 International License. Read Full License 


\section{Abstract \\ Background}

The cardiovascular diseases (CVDs) are becoming a critical threat to our lives in these years. It is now widely accepted that platelets play an important role in cardiovascular disease as they have a fundamental role in thrombosis. Therefore, many drugs or natural substances have been developed to treat CVDs. Cudrania tricuspidata (C. tricuspidata) is a regional plant containing various flavonoids and xanthones, and various physiological activities have been reported. Therefore, we evaluated antiplatelet effects using artocarpesin isolated from C. tricuspidata.

\section{Methods}

The in vitro effects of artocarpesin on platelets was assessed using measurement of calcium mobilization and serotonin release, glycoprotein Ilb/Illa activation, clot retraction and phosphorylation of signaling molecules.

\section{Results}

Artocarpesin inhibited human platelet aggregation, calcium mobilization, glycoprotein Ilb/llla activation and thrombin-induced clot retraction through the regulation of associated signaling molecules such as vasodilator-stimulated phosphoprotein (VASP) and inositol 1, 4, 5-triphosphate receptor I ( $\left(\mathrm{P}_{3} \mathrm{RI}\right)$, and on the dephosphorylation of cytosolic phospholipase $\mathrm{A}_{2}\left(\mathrm{CPLA}_{2}\right)$, mitogen-activated protein kinases $\mathrm{p} 38$, JNK and phosphoinositide 3-kinase (PI3K)/Akt.

\section{Conclusions}

This study highlights that artocarpesin has inhibitory effects on platelet activities and thrombus formation and has potential value for preventing platelet-induced cardiovascular diseases.

\section{Background}

In normal circulation of blood, collagen cannot bind with platelets. However, damaged vascular wall shows collagen fibers and interact with circulatory platelets to start hemostasis [1, 2]. After platelet activation, phosphatidylinositol 4,5-bisphosphate hydrolyzes into inositol 1,4,5-trisphosphate $\left(\mathrm{IP}_{3}\right)$ and $\mathrm{IP}_{3}$ induced calcium mobilization affecting granule release [3-5]. These signaling cascades are called "inside-out signaling" and activated platelets occurs structural change of glycoprotein Ilb/llla (allb/ 33 ). The signaling mechanism induced by activated allb/ $\beta 3$ is called "outside-in signaling pathway". During inside-out signaling, endogenous enzyme produces thromboxane $A_{2}$ affecting circulatory platelets [6-8]. 
Therefore, since platelets cause hemostasis and thrombosis, it is important to balance platelet activity [9] and there is a need to develop various substances to inhibit platelets to reduce CVDs [10].

In normal blood circulation, vascular endothelial cells release nitric oxide and prostaglandin $\mathrm{I}_{2}$ which makes the platelets inactive. These molecules elevate nucleotides such as cyclic-adenosine monophosphate (CAMP) and cyclic-guanosine monophosphate (cGMP) within circulatory platelets and activate dependent kinases [11]. Vasodilator-stimulated phosphoprotein (VASP) and inositol 1, 4, 5triphosphate receptor type $\mathrm{I}\left(\mathrm{IP}_{3} \mathrm{RI}\right)$ are major substrates of protein kinase $A$ and protein kinase $\mathrm{G}$ and VASP contributes to allb/ $\beta_{3}$ affinity and $I P_{3} R I$ affects $\left[\mathrm{Ca}^{2+}\right]_{i}$ mobilization. However, It has been reported that if cAMP/cGMP-dependent kinases phosphorylate VASP and $\mathrm{IP}_{3} \mathrm{RI}, \mathrm{allb} / \beta_{3}$ activation and $\left[\mathrm{Ca}^{2+}\right]_{\mathrm{i}}$ mobilization are inhibited $[12,13]$.

Cudrania tricuspidate (C. tricuspidate) has been investigated various substances and biological activities. Therefore, we searched for a new substance from $C$. tricuspidate. We have confirmed the effects of isoderrone and steppogenin in previous studies $[14,15]$. In addition, it has been reported that root extract of $C$. tricuspidate inhibited rat platelet aggregation [16]. Therefore, we investigated a more diverse material in C. tricuspidate and found artocarpesin.

\section{Methods}

\section{Chemicals and reagents}

Artocarpesin was purchased from ChemFaces (Wuhan, China). Collagen was purchased form ChronoLog Co. (Havertown, PA, USA). Fura 2-AM (2-acetoxymethyl) and alexa fluor 488-conjugated fibrinogen were obtained from Invitrogen (Eugene, OR, USA). Serotonin ELISA kit was purchased from Labor Diagnostika Nord GmbH and CO. (Nordhorn, Germany). Bicinchoninic acid protein assay kit was purchased form Pierce Biotechnology (IL, USA). Cayman chemical (Ann Arbor, MI, USA) offered thromboxane $B_{2}$ assay kit, cAMP, cGMP enzyme immunoassay kit. Cell signaling (Beverly, MA, USA) supplied the lysis buffer and antibodies against phospho-p38, phosphor-JNK (1/2), phospho-VASP $\left(\mathrm{Ser}^{157}\right)$, phospho-VASP $\left(\mathrm{Ser}^{239}\right)$, phospho-cPLA $2\left(\mathrm{Ser}^{505}\right)$, phosphor-PI3K $\left(\mathrm{Tyr}^{458}\right)$, phospho-Akt $\left(\mathrm{Ser}^{473}\right)$, phospho-inositol-3-phosphate receptor type I $\left(\mathrm{Ser}^{1756}\right)$, phosphor-PLC $\mathrm{y}_{2}\left(\mathrm{Tyr}^{759}\right), \beta$-actin, and anti-rabbit secondary antibody. Fibronectin-coated cell adhesion kit as procured from Cell Biolabs (San Diego, CA, USA).

\section{Human platelets suspension}

Korean Red Cross Blood Center (Suwon, Korea) supplied human platelet-rich plasma (PRP) for research, and study protocols were approved by the Public Institutional Review Board at the National Institute for Bioethics Policy (PIRB-P01-201812-31-007, Seoul, Republic of Korea). The suspension of platelets was adjusted to $5 \times 10^{8} / \mathrm{mL}$ concentration according to the previous research $[17,18]$. 


\section{Platelet aggregation}

For in vitro platelet aggregation, human platelets suspension $\left(10^{8} / \mathrm{mL}\right)$ was pre-incubated for 3 min in presence or absence of artocarpesin along with $2 \mathrm{mM} \mathrm{CaCl}_{2}$ at $37^{\circ} \mathrm{C}$, then collagen $(2.5 \mu \mathrm{g} / \mathrm{mL})$ was added for stimulation. Dimethyl sulfoxide solution $(0.1 \%)$ was used to dissolve the artocarpesin. Platelet aggregation was measured for 7 minutes under stirring condition. The change in light transmission is converted into the aggregation rate (\%). Platelet aggregation was monitored using an aggregometer (Chrono-Log, Havertown, PA, USA).

\section{Cytotoxicity measurement}

Cytotoxicity of artocarpesin was conducted through lactate dehydrogenase leakage assay. Human platelets $\left(10^{8} / \mathrm{mL}\right)$ was incubated with artocarpesin $(40$ to $100 \mu \mathrm{M})$ for 1 hour and centrifuged at $12,000 \mathrm{~g}$. The supernatant was used to detect the lactate dehydrogenase using ELISA reader (TECAN, Salzburg, Austria).

\section{Calcium mobilization}

The Fura 2-AM $(5 \mu \mathrm{M})$ added PRP and incubated for $60 \mathrm{~min}$. After incubation, human platelets suspension was washed with washing buffer. After washing step, platelets were suspended using suspending buffer and the suspension of platelets was adjusted to $5 \times 10^{8} / \mathrm{mL}$ concentration. The Fura 2-AM loaded platelet suspension was pre-incubated with artocarpesin (40 to $100 \mu \mathrm{M})$ for $3 \mathrm{~min}$ at $37^{\circ} \mathrm{C}$ then added collagen $(2.5 \mu \mathrm{g} / \mathrm{mL})$. The calcium mobilization was measured using a spectro-fluorometer (Hitachi F-2700, Tokyo, Japan) and Grynkiewicz method was used for calculate the $\left[\mathrm{Ca}^{2+}\right]_{i}$ values [19].

\section{Measurement of Thromboxane $B_{2}$ production}

Thromboxane $A_{2}\left(T X A_{2}\right)$ is synthesized in platelets and quickly transforms into thromboxane $B_{2}\left(T X B_{2}\right)$, therefore, $T X A_{2}$ production was measured by detecting $T X B_{2}$ production. After platelet activation, the reaction was stopped by adding indomethacin $(0.2 \mathrm{mM})$ in EDTA $(5 \mathrm{mM})$. The TXB 2 was detected using ELISA reader (TECAN, Salzburg, Austria).

\section{Serotonin release detection}

Platelet aggregation was conducted for $7 \mathrm{~min}$ at $37^{\circ} \mathrm{C}$ with artocarpesin, then reaction cuvette place onto ice in order to terminate serotonin release for $3 \mathrm{~min}$. After termination, the reaction mixture was centrifuged and the supernatant was used. The serotonin was detected using ELISA reader (TECAN, Salzburg, Austria).

\section{Western blotting analysis}

After platelet aggregation, platelets are dissolved using lysis buffer. The amount of dissolved protein was calculated and proteins $(15 \mu \mathrm{g})$ were divided by $8 \%$ SDS-PAGE. After electrophoresis, proteins are 
transferred onto membranes and treated primary $(1: 1,000)$ and secondary antibodies $(1: 10,000)$. Western blotting was performed using the same sample separated after the platelet aggregation experiment. Western blotting analysis was conducted by using the Quantity One, Ver. 4.5 (BioRad, Hercules, CA, USA).

\section{Fibrinogen binding to allb/ $\beta 3$}

After platelet aggregation for $7 \mathrm{~min}$, the reaction mixture was incubated with alexa flour 488-conjugated fibrinogen for 5 mins. After incubation, $0.5 \%$ paraformaldehyde was added to fix the binding between platelet integrin and fibrinogen marker. All procedures of fibrinogen binding assay were conducted in the dark condition. The binding assay was measured using flow cytometry (BD Biosciences, San Jose, CA, USA), and results were presented by the CellQuest software (BD Biosciences).

\section{Fibronectin adhesion assay}

Human platelets $\left(10^{8} / \mathrm{mL}\right.$ ) was placed in fibronectin coated wells (bovine serum albumin coated well is used as a negative control) and incubated with artocarpesin in the presence of collagen $(2.5 \mu \mathrm{g} / \mathrm{mL})$ for $1 \mathrm{~h}$ at $37^{\circ} \mathrm{C}$. After incubation, wells were washed using PBS buffer and added cell stain solution for 10 min. After that, extraction solution was added and each extraction was measured by ELISA reader (TECAN, Salzburg, Austria).

\section{Platelet-mediated fibrin clot retraction}

Human platelet-rich plasma $(300 \mu \mathrm{L})$ was incubated with artocarpesin for $30 \mathrm{~min}$ at $37^{\circ} \mathrm{C}$, and clot retraction was triggered by adding thrombin $(0.05 \mathrm{U} / \mathrm{mL})$. After reacting for $15 \mathrm{~min}$, pictures of fibrin clot were taken using a digital camera. Image J Software (v1.46) was used to calculate the clot area (National Institutes of Health, USA).

\section{Statistical analyses}

Experimental data have been presented as the mean \pm standard deviation included with the various number of observations. To determine major differences among groups, Analysis of variance was performed followed by Tukey-Kramer method. SPSS 21.0.0.0 software (SPSS, Chicago, IL, USA) was employed for statistical analysis and $p<0.05$ values were considered as statistically significant.

\section{Results}

\section{Effects of artocarpesin on human platelets aggregation and cytotoxicity}

Platelets suspension was incubated with various concentrations of artocarpesin (40 to $100 \mu \mathrm{M}, \mathrm{Fig}$. 1A) without stimulation of collagen for $7 \mathrm{~min}$, but the light transmission was not changed (Fig. 1B). However, collagen-induced platelet aggregation treated with artocarpesin (40 to $100 \mu \mathrm{M})$ was decreased dosedependently. Its inhibitory degree was $22.1,51.2,85.8$, and $96.7 \%$, respectively and half maximal inhibitory concentration $\left(\mathrm{IC}_{50}\right)$ was $58.3 \mu \mathrm{M}$ (Fig. 1C). To investigate the cytotoxicity of artocarpesin, we 
used various concentrations of artocarpesin. As shown in Fig. 1D, artocarpesin ( 40 to $100 \mu \mathrm{M})$ did not affect lactate dehydrogenase release.

\section{Effects of artocarpesin on $\left[\mathrm{Ca}^{2+}\right]_{\mathrm{i}}$ mobilization, $\mathrm{IP}_{3} \mathrm{RI}$ phosphorylation, serotonin secretion, JNK phosphorylation}

Intracellular $\left(\left[\mathrm{Ca}^{2+}\right]_{j}\right)$ is a crucial essential factor for platelet aggregation and activation, thus we focused the effect of artocarpesin on $\left[\mathrm{Ca}^{2+}\right]_{i}$ mobilization. As shown in Fig. $2 \mathrm{~A},\left[\mathrm{Ca}^{2+}\right]_{i}$ mobilization were elevated from $105.2 \pm 0.6 \mathrm{nM}$ to $770.6 \pm 8.4 \mathrm{nM}$ by collagen $(2.5 \mu \mathrm{g} / \mathrm{mL})$. However, artocarpesin dose-dependently reduced the increased $\left[\mathrm{Ca}^{2+}\right]_{i}$ levels. To confirm the $\left[\mathrm{Ca}^{2+}\right]_{\mathrm{i}}$ mobilization regulation, we investigated $\mathrm{Ca}^{2+}$ control signaling molecule, inositol 1, 4, 5-triphosphate receptor type I $\left(\mathrm{IP}_{3} \mathrm{RI}\right)$. As shown in Fig. 2B, artocarpesin $(80$ to $100 \mu \mathrm{M})$ increased $\mathrm{IP}_{3} \mathrm{RI}$ phosphorylation in collagen-induced human platelets. This result means that the decrease of $\left[\mathrm{Ca}^{2+}\right]_{i}$ level by artocarpesin is due to change of $\mathrm{IP}_{3} \mathrm{RI}$. Next, we examined whether artocarpesin affect serotonin release in $\delta$-granules. As shown in Fig. $2 \mathrm{C}$, artocarpesin dose-dependently inhibited collagen-stimulated serotonin secretion. The JNK1 is involved in platelet secretion [20], thus we investigated JNK (1/2) phosphorylation by artocarpesin. As shown in Fig. 2D, artocarpesin decreased JNK1 phosphorylation in collagen-induced human platelets.

\section{Effects of artocarpesin on fibrinogen binding to integrin allb/ $\beta_{3}$, fibronectin adhesion and VASP phosphorylation and PI3K/Akt dephosphorylation}

Next, we investigated allb/ $\beta_{3}$ activation, leading integrin-mediated outside-in signaling. Collagen elevated the allb/ $\beta_{3}$ activation, with a binding rate of $82.5 \pm 3.1 \%$ (Fig. 3A, 3B). However, artocarpesin decreased the binding force of fibrinogen dose-dependently (Fig. 3A, 3B). The allb/ $\beta 3$ can interact with fibronectin. Therefore, we examined whether artocarpesin affect fibronectin adhesion. As shown in Fig. 3C, fibronectin adhesion was suppressed by artocarpesin dose-dependently.

It is well known that phosphorylated VASP $\left(\operatorname{Ser}^{157}, \operatorname{Ser}^{239}\right)$ acts as a negative signaling in $\mathrm{allb} / \beta_{3}$ and phosphorylated phosphoinositide 3-kinase (PI3K)/Akt has been known as a positive signaling in allb/ $\beta_{3}$ $[21,22]$. Thus, we examined whether artocarpesin affects its phosphorylation. Collagen-induced VASP phosphorylation was increased by artocarpesin dose-dependently (Fig. 3D, 3E) but, PI3K/Akt phosphorylation was suppressed by artocarpesin dose-dependently (Fig. 3F, 3G). These results mean that the decrease of allb/ $\beta_{3}$ affinity by artocarpesin is due to VASP $\left(\operatorname{Ser}^{157}, \operatorname{Ser}^{239}\right)$ phosphorylation and PI3K $\left(\mathrm{Tyr}^{458}\right) /$ Akt $^{\left(\mathrm{Ser}^{473}\right)}$ dephosphorylation.

\section{Measurement thromboxane $A_{2}$ production, dephosphorylation of $\mathrm{CPLA}_{2}, \mathrm{p} 38$ and cyclic nucleotides}

We investigated $\mathrm{TXA}_{2}$ production associated signaling molecule. Collagen $(2.5 \mu \mathrm{g} / \mathrm{mL})$ stimulated human platelet produced $\mathrm{TXA}_{2}$ (determined as $\mathrm{TXB}_{2}$ ) from $1.2 \pm 0.2 \mathrm{nM}$ to $48.0 \pm 0.2 \mathrm{ng} / 10^{8}$ platelets. However, artocarpesin inhibited TXA 2 production dose-dependently (Fig. 4A). Next, we investigated TXA 2 
associated signaling molecules, cytosolic phospholipase $\mathrm{A}_{2}(\mathrm{CPLA})$ and p38 mitogen-activated protein kinases (p38). As shown in Fig. 4B and $4 C$, the $\mathrm{CPLA}_{2}$ and p38 are phosphorylated by collagen, but artocarpesin inhibited $\mathrm{CPLA} \mathrm{A}_{2}$ and $\mathrm{p} 38$ phosphorylation dose-dependently. These results mean that the decrease of $\mathrm{TXA}_{2}$ production by artocarpesin is due to $\mathrm{CPLA}$ and p38 dephosphorylation.

Next, we investigated the production of cAMP and cGMP in platelets. As shown in Fig. 4D and 4E, the production of CAMP and CGMP was increased by artocarpesin dose-dependently. These results mean that artocarpesin can increase cAMP and cGMP level in human platelet and activates cAMP/cGMP dependent signaling pathways affecting $\left[\mathrm{Ca}^{2+}\right]_{\mathrm{i}}$ mobilization and $\mathrm{allb} / \beta 3$ activation.

\section{Effects Of Artocarpesin On Clot Retraction And Plc Phosphorylation}

$\left[\mathrm{Ca}^{2+}\right]_{\mathrm{i}}$ mobilization leads inside-out signaling pathway and activated integrin allb/ $\beta 3$ facilitates outsidein signaling pathway which trigger various actions in platelets such as spreading, granule secretion, adhesion and clot retraction. Therefore, we examined the inhibitory effects of artocarpesin on clot retraction. Figure $5 \mathrm{~A}$ and $5 \mathrm{~B}$ shows thrombin-induced fibrin clot formation and contraction. Thrombin induced platelet rich plasma was contracted with an inhibition rate of $90.3 \%$ compare with unstimulated platelet rich plasma. However, the retraction was suppressed by artocarpesin ( 40 to $100 \mu \mathrm{M})$ dosedependently, with inhibitory degrees of $74.9,67.1,59.2$ and $50.0 \%$, respectively, compared with unstimulated platelet rich plasma (Fig. 5B). allb $\beta 3$ is an important medium for causing clot retraction. Activated allb $\beta 3$ triggers tyrosine phosphoryation of $\beta 3$ integrin tail and activates phospholipase $C_{Y 2}$ $\left(\mathrm{PLC}_{\mathrm{Y} 2}\right)$. The $\mathrm{PLC}_{\mathrm{Y} 2}$ has been reported to be crucial for spreading action of platelets and mediating clot retraction [23]. Therefore, we examined whether artocarpesin affects the phosphorylation of PLC $\mathrm{y}_{\mathrm{y}}$. As shown in Fig. $5 \mathrm{C}$, collagen elevated $\mathrm{PLC}_{\mathrm{\gamma} 2}$ phosphorylation was suppressed by artocarpesin dosedependently.

\section{Discussion}

C. tricuspidate is widespread throughout East Asia and used in ethnomedicine. In China, C. tricuspidate have been used as herbal teas for a long time. In Korea, $C$. tricuspidate have been widely used as traditional medicine against eczema, mumps and tuberculosis. Recently, about medical efficacy of $C$. tricuspidate, various studies are continuously being conducted and it has been reported that $C$. tricuspidate have various physiological activities including inflammation, diabetes, obesity, and tumor [24]. It has been reported that isoderrone, steppogenin and cudratricusxanthone $A$ isolated from $C$. tricuspidate have anti-platelets effects $[14,15,25]$. Thus, we searched new substances from $C$. tricuspidate to find new anti-platelet drug and we investigated that whether substances have antiplatelet effect on collagen-induced human platelets. We investigated 8 single compounds such as alboctalol, cudraxanthone D, cudraflavanon B, isolupalbigenin, xanthone V1a, cudraflavone B, shuterin, and artocarpesin and we found artocarpesin was an anti-platelet substance. Artocarpesin potently inhibited collagen-induced platelet aggregation (Table 1). Therefore, we checked $\mathrm{Ca}^{2+}$ mobilization, serotonin release, allb/ $\beta_{3}$ affinity, clot retraction and associated signaling molecules. 
Table 1

Effects of compounds isolated from Cudrania tricuspidata on collagen-induced human platelet aggregation

\begin{tabular}{|c|c|c|c|}
\hline Treatment & Aggregation (\%) & Treatment & Aggregation (\%) \\
\hline Collagen $(2.5 \mu \mathrm{g} / \mathrm{mL})$ & $91.8 \pm 1.3$ & & \\
\hline Cudraxanthone D & & Xanthone V1a & \\
\hline $40 \mathrm{uM}$ & $91.1 \pm 1.1$ & $40 \mathrm{uM}$ & $88.0 \pm 1.5$ \\
\hline $60 \mathrm{uM}$ & $91.2 \pm 1.2$ & $60 \mathrm{uM}$ & $91.0 \pm 1.1$ \\
\hline $80 \mathrm{uM}$ & $90.2 \pm 1.1$ & $80 \mathrm{uM}$ & $90.3 \pm 1.5$ \\
\hline $100 \mathrm{uM}$ & $92.2 \pm 0.5$ & 100 uM & $92.3 \pm 1.4$ \\
\hline Cudraflavanone B & & Cudraflavone B & \\
\hline $40 \mathrm{uM}$ & $91.0 \pm 0.7$ & $40 \mathrm{uM}$ & $91.7 \pm 0.5$ \\
\hline $60 \mathrm{uM}$ & $91.5 \pm 0.5$ & $60 \mathrm{uM}$ & $90.0 \pm 1.1$ \\
\hline $80 \mathrm{uM}$ & $89.6 \pm 1.2$ & $80 \mathrm{uM}$ & $91.7 \pm 1.3$ \\
\hline $100 \mathrm{uM}$ & $89.4 \pm 1.1$ & 100 uM & $92.0 \pm 1.5$ \\
\hline Alboctalol & & Shuterin & \\
\hline $40 \mathrm{uM}$ & $89.7 \pm 1.3$ & $40 \mathrm{uM}$ & $90.3 \pm 1.5$ \\
\hline $60 \mathrm{uM}$ & $90.7 \pm 0.8$ & $60 \mathrm{uM}$ & $92.1 \pm 0.8$ \\
\hline 80 uM & $91.3 \pm 0.9$ & $80 \mathrm{uM}$ & $88.1 \pm 1.1$ \\
\hline $100 \mathrm{uM}$ & $91.6 \pm 1.4$ & 100 uM & $90.4 \pm 1.2$ \\
\hline Isolupalbigenin & & Artocarpesin & \\
\hline $40 \mathrm{uM}$ & $92.3 \pm 1.5$ & $40 \mathrm{uM}$ & $71.5 \pm 1.3$ \\
\hline 60 uM & $91.7 \pm 1.2$ & $60 \mathrm{uM}$ & $44.8 \pm 1.0 *$ \\
\hline 80 uM & $89.7 \pm 1.4$ & $80 \mathrm{uM}$ & $13.0 \pm 2.2^{*}$ \\
\hline $100 \mathrm{uM}$ & $90.0 \pm 0.8$ & 100 uM & $3.0 \pm 0.8^{\star \star}$ \\
\hline
\end{tabular}

Artocarpesin suppressed $\left[\mathrm{Ca}^{2+}\right]_{\mathrm{i}}$ level and serotonin release through $\mathrm{IP}_{3} \mathrm{RI}\left(\mathrm{Ser}^{1756}\right)$ phosphorylation (Fig. 2B) and dephosphorylation of JNK1 (Fig. 2D). The activation of allb/ $\beta_{3}$ leads to a rapid binding to fibrinogen and fibronectin and triggers outside-in signaling. Our results clarified that artocarpesin downregulated allb/B3 activity (Fig. 3A, 3C) through upregulation of phosphorylation of VASP (Fig. 3D, 
3E) and downregulation of PI3K/Akt phosphorylation (Fig. 3F, 3G). Artocarpesin also suppressed $\mathrm{TXA}_{2}$ production through dephosphorylation of $\mathrm{CPLA}_{2}$ and p38 dose-dependently (Fig. 4B, 4C). Intracellular CAMP and CGMP are strong negative molecules and regulated by enzymes such as cyclic adenylate/guanylate cyclase, and phosphodiesterases. These cyclic nucleotides inhibit allb/ $\beta 3$ affinity and $\left[\mathrm{Ca}^{2+}\right]_{i}$ mobilization. In our study, artocarpesin increased cAMP and cGMP concentration (Fig. 4D, 4E) and these cyclic nucleotides can elevate the phosphorylation of VASP $\left(\operatorname{Ser}^{157}, \operatorname{Ser}^{239}\right)$ and IP ${ }_{3}^{R I}\left(\operatorname{Ser}^{1756}\right)$.

The interaction between allb/ $\beta 3$ and fibrin affect the clot formation [5]. Therefore, we investigated that whether artocarpesin affect thrombin-induced fibrin clot retraction. As shown in Fig. 5A, artocarpesin strongly suppressed the retraction. This result is achieved through inhibition of $\mathrm{Ca}^{2+}$ mobilization, thromboxane $A_{2}$ production and allb/ $\beta 3$ inactivation. We confirmed these results through inhibitionrelated signaling molecules such as $\mathrm{IP}_{3} \mathrm{RI}, \mathrm{JNK} 1$, VASP, PI3K/Akt, $C P L A_{2}$ and $\mathrm{p} 38$. Therefore, we confirmed that inhibitory effects of artocarpesin on anti-platelet function and anti-thrombus functions are due to the elevated cyclic nucleotides and dephosphoryalation of MAPKs. Through the all experimental results, we believe that artocarpesin is valuable as a potential treatment for cardiovascular diseases. As evidence, PDE inhibitors (cilostazol, dipyridamole) have been reported to have therapeutic effects on thrombosis to increase cyclic nucleotides production [27, 28].

\section{Conclusion}

This study found that artocarpesin decreases calcium mobilization, fibrinogen-binding to allb/ $\beta_{3}$, fibronectin adhesion and thrombin-facilitated clot retraction through the regulation of associated signaling molecules such as $\mathrm{IP}_{3} \mathrm{RI}, \mathrm{JNK}, \mathrm{CPLA}, \mathrm{p} 38$, VASP, PI3K/Akt and PLC $\mathrm{P}_{\mathrm{y} 2}$. Therefore, we suggest that artocarpesin from the root and stems of $C$. tricuspidata would be a useful compound for prevention of thrombosis.

\section{Abbreviations}

CVDs

cardiovascular diseases; VASP:vasodilator-stimulated phosphoprotein; $\mathrm{IP}_{3} \mathrm{RI}$ :inositol 1, 4, 5-triphosphate receptor I; MAPKs:mitogen-activated protein kinases; cAMP:cyclic adenosine monophosphate; cGMP:cyclic guanosine monophosphate; $\mathrm{TXA}_{2}$ :Thromboxane $\mathrm{A}_{2} ; \mathrm{PLCY}_{2}$ :phospholipase $\mathrm{C \gamma}_{2}$; PI3K:phosphoinositide 3-kinase

\section{Declarations}

\section{Ethics approval and consent to participate}

Ethical approval for the study was acquired from the Public Institutional Review Board at the National Institute for Bioethics Policy (PIRB-P01-201812-31-007, Seoul, Republic of Korea). 


\section{Consent for publication}

Not applicable.

\section{Availability of data and materials}

The data will be accessible by contacting the corresponding author of this study.

\section{Competing interests}

The authors declare no conflict of interest.

\section{Funding}

This study was supported by a grant (NRF-2018R1C1B5083580) from the Basic Science Research Program via the National Research Foundation of Korea (NRF), funded by the Ministry of Education, Science and Technology, Korea.

\section{Authors' contributions}

Conception and design of the experiment: MHR, HWK. Performance of the experiment: JHS, HWK. Analysis and arrangement of the data: JHS, MI, YYL, HWK. Contribution of reagents, materials, and tool: JHS, HWK. Contribution of manuscript preparation: MHR, HWK. All authors read and approved the final manuscript.

\section{Acknowledgements}

The authors would like to express their sincere gratitude to all the participants.

\section{Author's information}

${ }^{1}$ Department of Biomedical Laboratory Science, Catholic Kwandong University, Gangneung 25601, Korea.

${ }^{2}$ Laboratory of Physiology and Cell Signaling, College of Veterinary Medicine, Kyungpook National University, Daegu 41566 , Korea. ${ }^{3}$ Department of Oral Biology, University of Illinois at Chicago, Chicago, Illinois. ${ }^{4}$ Department of Biomedical Laboratory Science, Far East University, Eumseong 27601, Korea.

\section{References}

1. Chen $\mathrm{H}$, Kahn ML. Reciprocal signaling by integrin and nonintegrin receptors during collagen activation of platelets. Molecular and Cellular Biology. 2003;23:4764-4777.

2. Farndale RW. Collagen-induced platelet activation. Blood Cells Molecules and Diseases. 2006;36:162-165.

3. Schwartz SM, Heimark RL, Majesky MW. Developmental mechanisms underlying pathology of arteries. Physiological Reviews. 1990;70:1177-1209. 
4. Payrastre B, Missy K, Trumel C, Bodin S, Plantavid M, Chap H. The integrin allb/ $\beta 3$ in human platelet signal transduction. Biochemical Pharmacology. 2000;60:1069-1074.

5. Phillips DR, Nannizzi-Alaimo L, Prasad KS. $\beta 3$ tyrosine phosphorylation in allb $\beta 3$ (platelet membrane GP Ilb-Illa) outside-in integrin signaling. Thrombosis and Haemostasis. 2001;86:246-258.

6. Needleman P, Moncada S, Bunting S, Vane JR, Hamberg M, Samuelsson B. Identification of an enzyme in platelet microsomes which generates thromboxane A2 from prostaglandin endoperoxides. Nature. 1976:261:558-560.

7. Patrono C. Aspirin as an antiplatelet drug. New England Journal of Medicine. 1994;330:1287-1294.

8. Cheng Y, Austin SC, Rocca B, Koller BH, Coffman TM, Grosser T, etal. Role of prostacyclin in the cardiovascular response to thromboxane A2. Science. 2002;296:539-541.

9. Laurent V, Loisel TP, Harbeck B, Wehman A, Gröbe L, Jockusch BM, et al. Role of proteins of the Ena/VASP family in actin-based motility of Listeria monocytogenes. Journal of Cell Biology. 1999;144:1245-1258.

10. Andrews RK, Berndt MC. Platelet physiology and thrombosis. Thrombosis Research. 2004; 144:447453.

11. Smolenski A. Novel roles of cAMP/cGMP-dependent signaling in platelets. Journal of Thrombosis and Haemostasis. 2012;10:167-176.

12. Schwarz UR, Walter U, Eigenthaler M. Taming platelets with cyclic nucleotides. Biochemical Pharmacology. 2001; 62:1153-1161.

13. Sudo T, Ito H, Kimura Y. Phosphorylation of the vasodilator-stimulated phosphoprotein (VASP) by the anti-platelet drug, cilostazol, in platelets. Platelets. 2003;14:381-390.

14. Shin JH. Inhibitory effects of isoderrone on platelet aggregation through regulation of cyclic nucleotides. Journal of the Korean Society of Food Science and Nutrition. 2020;49:796-802.

15. Shin JH, Ha JY, Kwon HW. Inhibitory Actions of Steppogenin on Platelet Activity Through Regulation of Glycoprotein Ilb/llla and $\mathrm{Ca}^{2+}$ Mobilization. Korean Journal of Pharmacognosy. 2020;51:100-106.

16. Ro JY. Cho HJ. Cudrania Tricuspidata root extract (CTE) has an anti-platelet effect via cGMPdependent VASP phosphorylation in human platelets. Journal of the Korea Academia-Industrial Cooperation Society. 2019; 20: 298-305.

17. Shin JH, Kwon HW, Lee DH. Ginsenoside F4 inhibits platelet aggregation and thrombus formation by dephosphorylation of IP3RI and VASP. Journal of Applied Biological Chemistry. 2019;62:93-100.

18. Born GVR, Hume M. Effects of the numbers and sizes of platelet aggregates on the optical density of plasma. Nature. 1967;215:1027-1029.

19. Grynkiewicz G, Poenie M, Tsien RY. A new generation of $\mathrm{Ca} 2$ + indicators with greatly improved fluorescence properties. Journal of Biological Chemistry. 1985;260:3440-3450.

20. Adam F, Kauskot A, Nurden P, Sulpice E, Hoylaerts MF, Davis RJ, et al. Platelet JNK1 is involved in secretion and thrombus formation. Blood. 2010;115:4083-4092. 
21. Zhang J, Zhang J, Shattil SJ, Cunningham MC, Rittenhouse SE. Phosphoinositide 3-kinase gamma and p85/phosphoinositide 3-kinase in platelets. Relative activation by thrombin receptor or betaphorbol myristate acetate and roles in promoting the ligand-binding function of alphallbbeta3 integrin. Journal of Biological Chemistry. 1996;271:6265-6272.

22. Chen J, De S, Damron DS, Chen WS, Hay N, Byzova TV. Impaired platelet responses to thrombin and collagen in AKT-1-deficient mice. Blood. 2004;104:1703-1710.

23. Suzuki-Inoue K, Hughes CE, Inoue O, Kaneko M, Cuyun-Lir O, Takafuta T, et al. Involvement of SrC kinases and PLCY2 in clot retraction. Thrombosis Research. 2007;120:251-258.

24. Xin LT, Yue SJ, Fan YC, Wu JS, Yan D, Guan HS, et al. Cudrania tricuspidata: an updated review on ethnomedicine, phytochemistry and pharmacology. RSC advances. 2017;7:31807-31832.

25. Yoo H, Ku SK, Lee W, Kwak S, Baek YD, Min BW, et al. Antiplatelet, anticoagulant, and profibrinolytic activities of cudratricusxanthone A. Archives of pharmacal research. 2014;37:1069-1078.

26. Gao J, Tao J, Liang W, Zhao M, Du X, Cui S, et al. Identification and characterization of phosphodiesterases that specifically degrade 3'3'-cyclic GMP-AMP. Cell Research. 2015;25:539-550.

27. Haslam RJ, Dickinson NT, Jang EK. Cyclic nucleotides and phos- phodiesterases in platelets. Thrombosis and Haemostasis. 1999;82:412-423.

28. Menshikov MY, Ivanova K, Schaefer M, Drummer C, Gerzer R. Influence of the cGMP analog 8-PCPTcGMP on agonist-induced increases in cytosolic ionized $\mathrm{Ca}^{2+}$ and on aggregation of human platelets. European Journal of Pharmacology. 1993;245:281-284.

\section{Figures}


A<smiles>CC(C)=CCc1c(O)cc2oc(-c3ccc(O)cc3O)cc(=O)c2c1O</smiles>

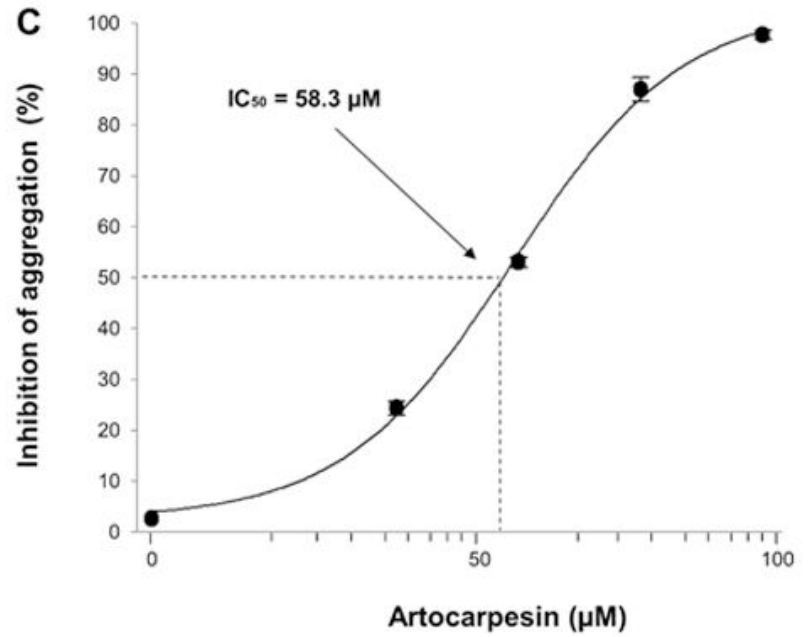

Artocarpesin $(\mu \mathrm{M})$

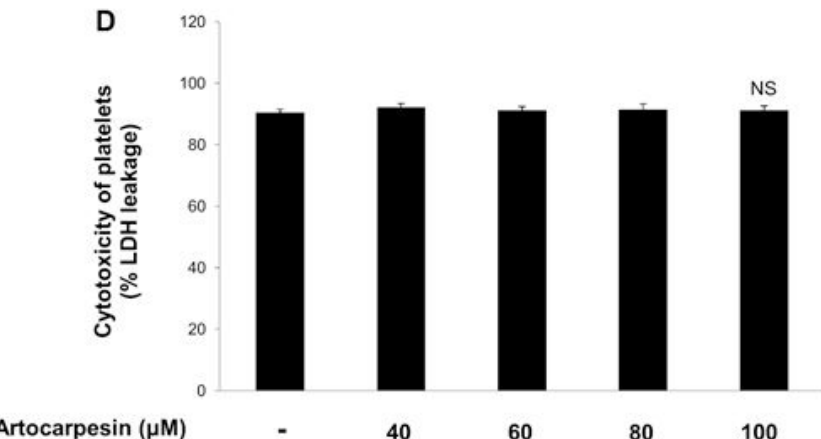

Collagen $(2.5 \mu \mathrm{g} / \mathrm{mL})$

Artocarpesin $(\mu \mathrm{M})$

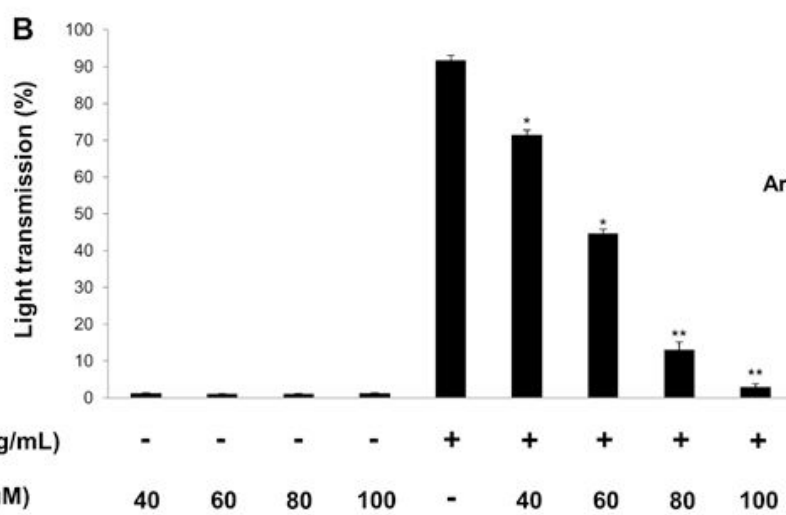

\section{Figure 1}

Effects of artocarpesin on platelet aggregation, half maximal inhibitory concentration, and cytotoxicity (A) Chemical structure of artocarpesin (B) Effect of artocarpesin on collagen-induced human platelet aggregation. (C) Half maximal inhibitory concentration (IC50) value of artocarpesin in collagen-induced human platelet aggregation. (D) Effect of artocarpesin on cytotoxicity. Platelet aggregation and cytotoxicity were carried out as described in "Materials and Methods" section. The data are expressed as 
the mean \pm standard deviation $(n=4) .{ }^{*} p<0.05,{ }^{*} p<0.01$ versus each agonist-stimulated human platelets. NS, not significant.
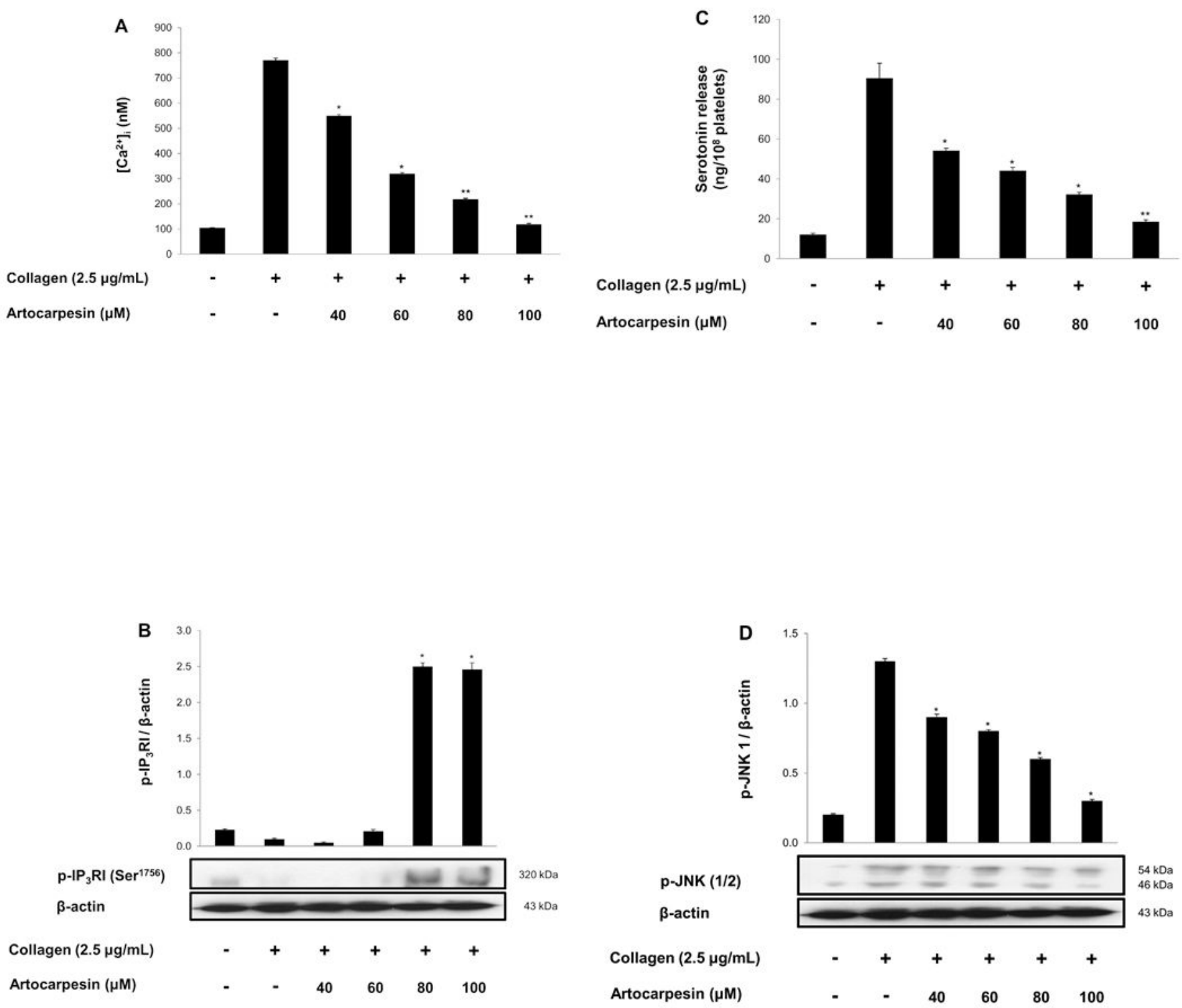

Figure 2

Effects of artocarpesin on [Ca2+]i mobilization, Serotonin release, TXA2 generation, and IP3RI and JNK (1/2) phosphorylation (A) Effect of artocarpesin on collagen-induced [Ca2+]i mobilization. (B) Effect of artocarpesin on collagen-induced IP3RI phosphorylation. (C) Effect of artocarpesin on collagen-induced 
serotonin release. (D) Effect of artocarpesin on collagen-induced JNK (1/2) phosphorylation. Measurement of [Ca2+]i mobilization, serotonin release, Western blot was performed as described in "Materials and Methods" section. The data are expressed as the mean \pm standard deviation $(n=4)$. ${ }^{*} p<0.05,{ }^{*} \mathrm{p}<0.01$ versus the collagen-stimulated human platelets.

A
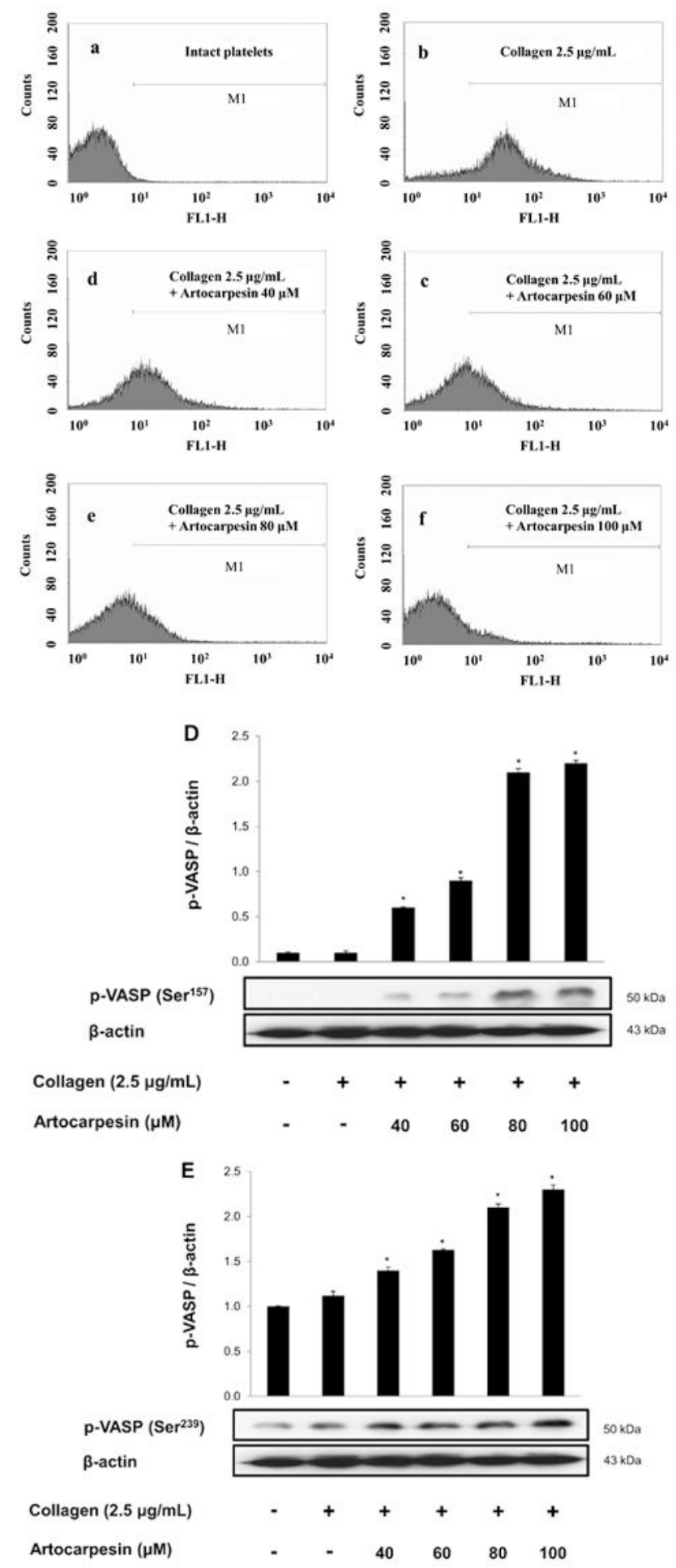

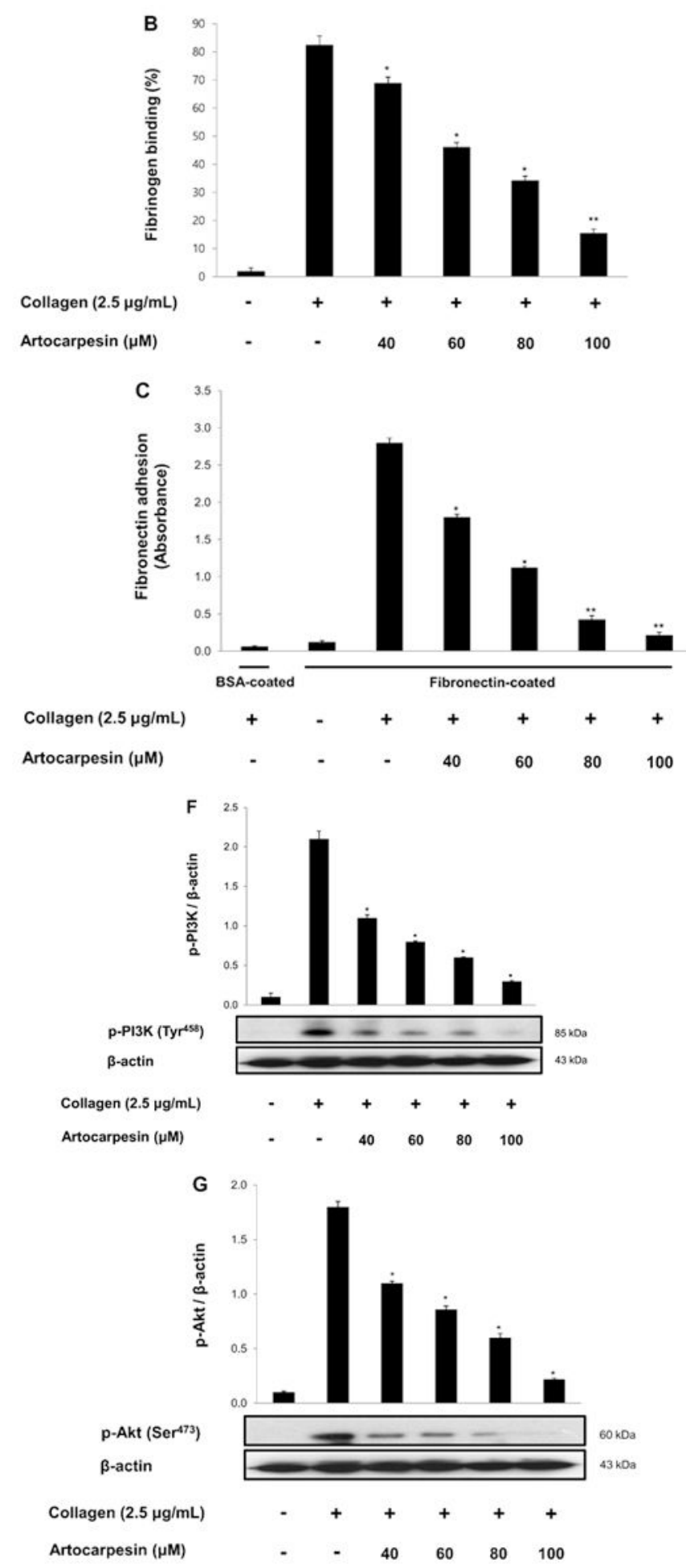

Figure 3 
Effects of artocarpesin on fibrinogen binding to allb/ $\beta 3$, fibronectin adhesion and VASP and PI3K/Akt phosphorylation (A) The flow cytometry histograms on fibrinogen binding. (B) Effects of artocarpesin on collagen-induced fibrinogen binding (\%). (C) Effects of artocarpesin on collagen-induced fibronectin adhesion. (D) Effect of artocarpesin on collagen-induced VASP (Ser157) phosphorylation. (E) Effect of artocarpesin on collagen-induced VASP (Ser239) phosphorylation. (F) Effect of artocarpesin on collageninduced PI3K (Tyr458) phosphorylation. (G) Effect of artocarpesin on collagen-induced Akt (Ser473) phosphorylation. Measurement of fibrinogen binding, fibronectin adhesion, and Western blot was carried out as described in "Materials and Methods" section. The data are expressed as the mean \pm standard deviation $(n=4) .{ }^{*} p<0.05,{ }^{* *} p<0.01$ versus the collagen-stimulated human platelets. 


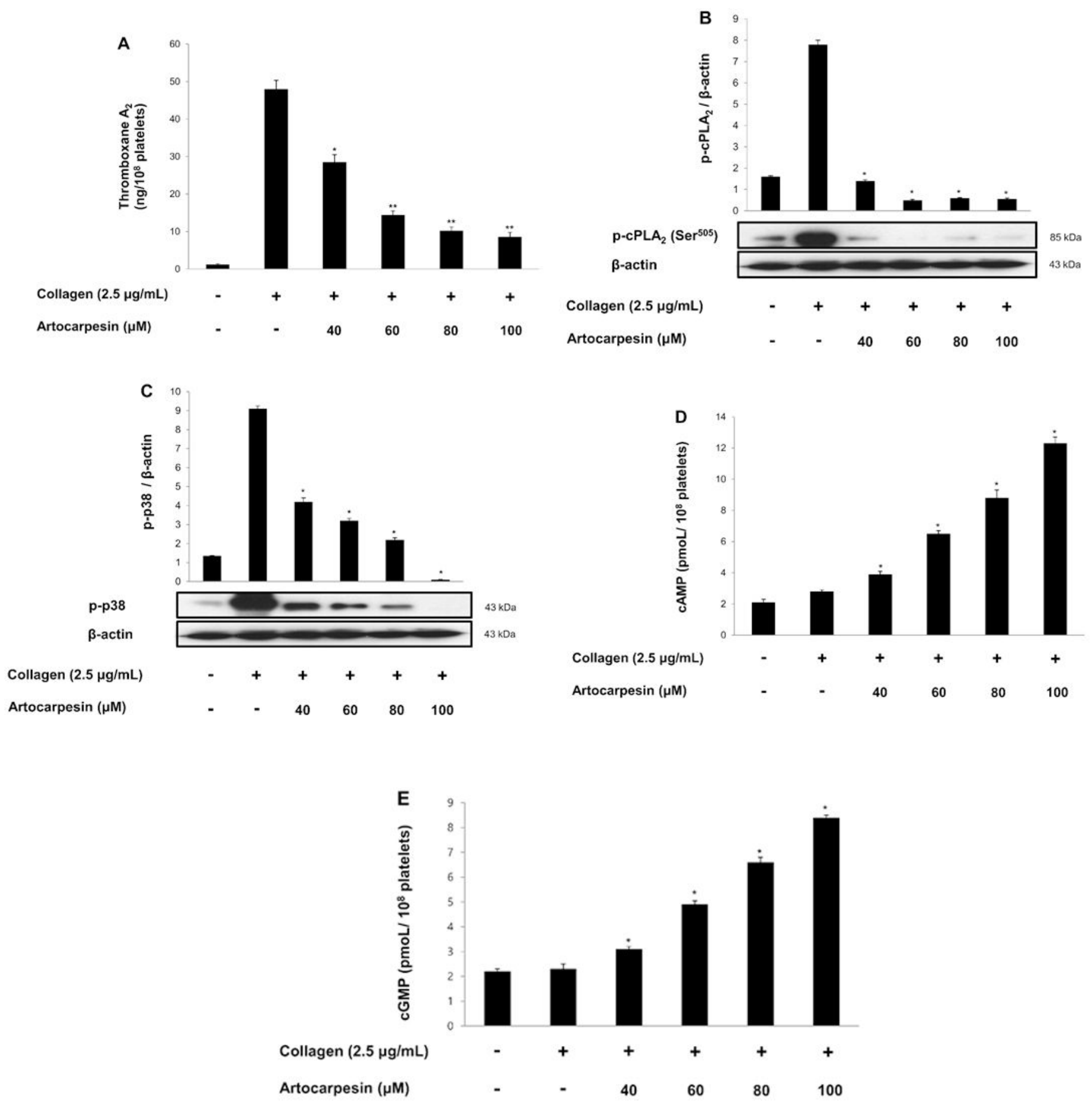

Figure 4

Effects of artocarpesin on TXA2 generation, cPLA2, p38phosphorylation and cyclic nucleotides (A) Effects of artocarpesin on collagen-induced TXA2 generation. (B) Effect of artocarpesin on collageninduced cPLA2 phosphorylation. (C) Effect of artocarpesin on collagen-induced p38 phosphorylation. (D) Effect of artocarpesin on collagen-induced cAMP production. (E) Effect of artocarpesin on collageninduced cGMP production. Measurement of TXA2 generation, Western blot and cyclic nucleotides level 
was performed as described in "Materials and Methods" section. The data are expressed as the mean \pm standard deviation $(n=4) .{ }^{*} p<0.05,{ }^{* *} p<0.01$ versus the collagen-stimulated human platelets.

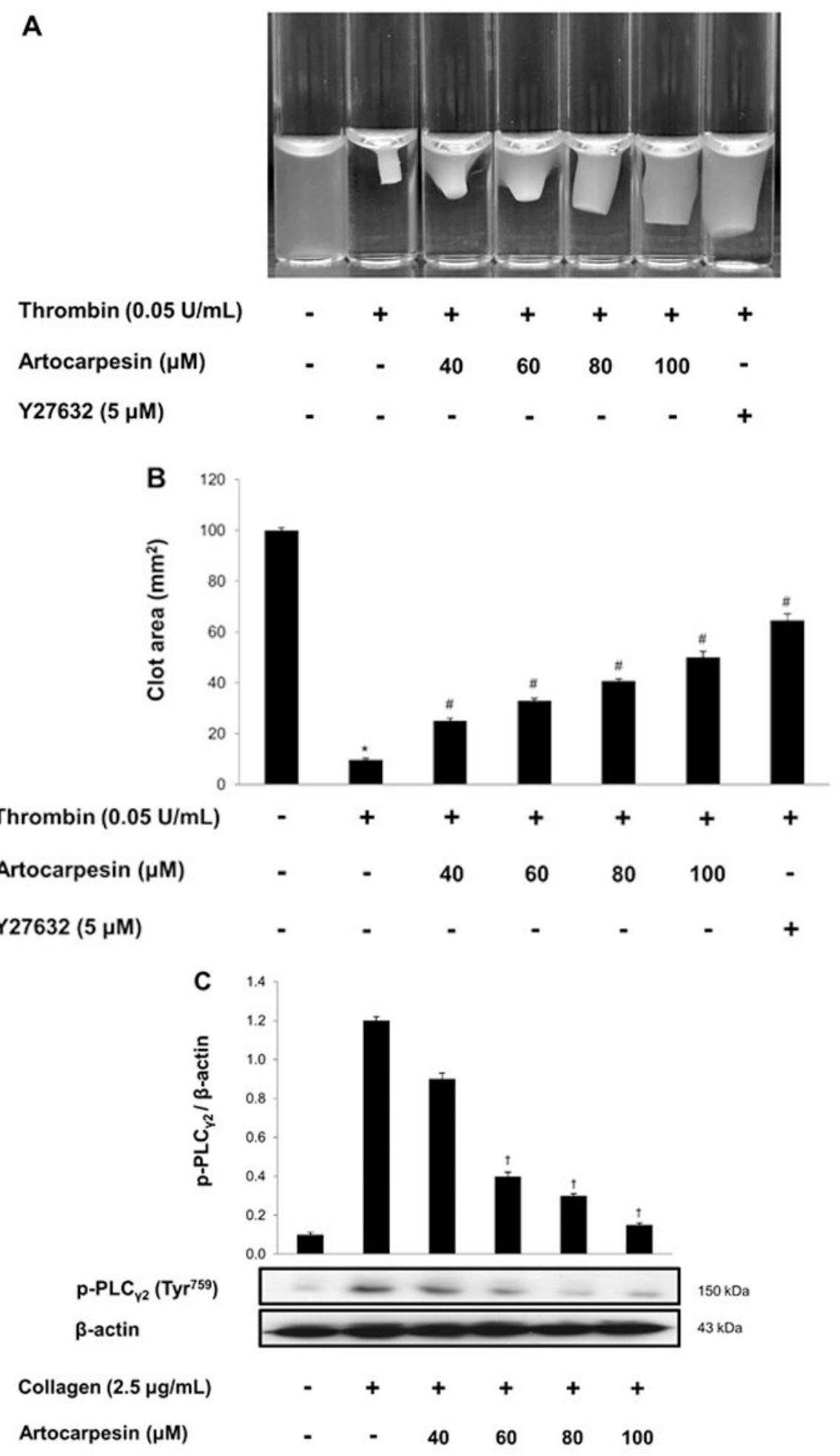

Figure 5

Effects of artocarpesin on fibrin clot retraction and PLCY2 phosphorylation (A) Photographs of fibrin clot (B) Effects of artocarpesin on thrombin-retracted fibrin clot (\%). (C) Effect of artocarpesin on collageninduced PLCY2 (Tyr759) phosphorylation. Quantification of fibrin clot retraction and Western blot was 
performed as describe in "Materials and Methods" section. The data are expressed as the mean \pm standard deviation $(n=4) .{ }^{*} p<0.05$ versus the unstimulated human PRP, $\# p<0.05$ versus the thrombinstimulated human PRP. $+p<0.05$ versus the collagen-stimulated human platelets.

\section{Supplementary Files}

This is a list of supplementary files associated with this preprint. Click to download.

- SupplementaryData.pdf 